\title{
Public Awareness of Geriatrics in the 50th Year of Geriatrics in Turkey
}

\author{
(1) Volkan Atmış, (1) Remzi Bahşi, (1) Hande Selvi Öztorun, (1) Çağlar Coşarderelioğlu, (1) Ahmet Yalçın, (1) Sevgi Aras, (1) Murat Varlı, \\ (1) Deniz Mut Sürmeli, (1) Tuğba Turgut
}

Ankara University Faculty of Medicine, Department of Internal Medicine, Division of Geriatrics, Ankara, Turkey

\begin{abstract}
Objective: Geriatrics focuses on health care of the elderly. Geriatrics has a history of about 50 years in Turkey. In order to increase the quality and quantity of geriatric services, geriatric awareness needs to be increased. This is possible only when the government, health workers and the community work together. We decided to do this study to determine the level of public awareness of geriatrics among elderly population in Turkey.

Materials and Methods: Between January 2018 and March 2019, we reached a total of 314 people over 60 years of age living in eight different districts of Ankara. It was questioned whether the patients knew geriatrics, and if they knew and truly described geriatrics, and they were asked how they had learned. Patients who knew geriatrics were asked whether they applied to any of the centers with a geriatrician in Ankara.
\end{abstract}

Results: Only $2.88 \%$ of the study population had geriatrics awareness. In general, participants with geriatrics awareness were found to be older in age, having higher mental scores and having less children.

Conclusion: In our country, the level of awareness of geriatrics is very low in its $50^{\text {th }}$ year.

Keywords: Geriatric awareness, geriatric, elderly

\section{Introduction}

Geriatrics focuses on health care of the older adults. It aims to either prevent, to treat or to control diseases and disabilities in older adults. Although The United Nations declared the age cutoff as $60+$ years to refer to the older adults, there is no set age at which adults may be under the care of a geriatrician. Rather, this decision is given by the individual's health needs, and the availability of a specialist. The term geriatrics comes from the Greek geron meaning "old man", and iatros meaning "healer".

Traditional Indian system of medicine, Ayurveda, is the first known health system similar to geriatrics. Here fatigue and physical exhaustion is described as the result of poor diet secondary to aging, and the older adults are recommended to avoid excessive physical or mental strain and consume a light but nutritious diet (1). Arabic physician Algizar (A.C. 898-980) wrote a book on the health of the older adults; sleep disorders, forgetfulness and causes of mortality were among the titles (2). Avicenna in 1025 was concerned with sleep, exercises, diet and constipation of the older adults (3). Byzantine Empire viewed aging as a natural and inevitable form of marasmus, caused by the loss of moisture in body tissue, they described the mental and physical symptoms of aging, recommending a diet rich in foods that provide heat and moisture, frequent bathing, massaging, rest, and low-intensity exercise regimens (4).

One of the first publications about geriatric medicine was published in 1849 by George Day, Diseases of Advanced Life (5). The first geriatric hospital was founded in Belgrade, Serbia and the term geriatrics was proposed in 1909 by Ignatz Leo Nascher (6).

Geriatrics began to spread in Northern Europe, America, Canada, Japan, Australia and Western Europe since the 1970s. As in the

Address for Correspondence: Volkan Atmış MD, Ankara University Faculty of Medicine, Department of Internal Medicine, Division of Geriatrics, Ankara, Turkey

Phone: +90 3125853577 E-mail: volkanatmis@hotmail.com ORCID: orcid.org/0000-0002-0080-6448

Received: Mar 28, 2019 Accepted: May 28, 2019

Cite this article as: Atmış V, Bahşi R, Selvi Öztorun H, Coşarderelioğlu Ç, Yalçın A, Aras S, Varlı M. Public Awareness of Geriatrics in the $50^{\text {th }}$ Year of Geriatrics in Turkey. Eur J Geriatr Gerontol 2019;1(1):24-28

๑Copyright 2019 by the Academic Geriatrics Society / European Journal of Geriatrics and Gerontology published by Galenos Publishing House. 
rest of the world, only internal medicine specialists in Turkey have the opportunity to be a geriatrician.

Geriatrics has about 50 years of history in Turkey. Prof. Dr. Şefik Ayhan is known as the first Turkish doctor to be interested in geriatrics (7). First geriatrics department in Turkey was inaugurated at Cerrahpaşa Faculty of Medicine in 1987, Ankara University in 1992 started to accept geriatric patients in 1992. According to Turkish Statistical Institute (TURKSTAT) March 2019 data, geriatricians work only in 16 cities in Turkey.

As of the end of 2018, there are totally 109 geriatricians and geriatrics fellows working privately or publicly working at 41 different centers in Turkey; 11 in Istanbul and Ankara, two in İzmir, Adana, Gaziantep, Kayseri and Erzurum, Bursa, Antalya, Konya, Mersin, Diyarbakır, Eskişehir, Malatya, Isparta and Kırıkkale. According to TURKSTAT data, no geriatrician employment was planned in 46 provinces as of March 2019.

According to TURKSTAT data, as the end of December 2018, Turkey's population has exceeded 80 million and nearly 10\% of this population is over 65 years of age. This means that the number of patients per geriatrician is approximately 800,000 in Turkey. According to the World Health Organization statistics, there are approximately 17 doctors per 10,000 patients in Turkey in 2014, indicating that the number of geriatricians should increase by more than 100 times to reach the average for this rate.

In order to increase the quality and quantity of geriatric services, geriatric awareness needs to be increased. And this is possible only when the government, health workers and the community work together. After 20 years from the inauguration of the first geriatric outpatient clinic, we decided to do this study to determine the prevalence of geriatrics awareness among older adults in the community in Turkey.

\section{Materials and Methods}

Between January 2018 and March 2019, we reached a total of 314 people over 60 years of age living in eight different districts of Ankara. Individuals over the age of 60 were called to the cultural centers by the municipal employees. Each person who was called and accepted to participate in the study was included in the study. Three doctors, two geriatrics nurses, one geriatrics technician and a geriatrics psychologist took part in the study. Demographic characteristics, diseases, medications, daily living activities (Katz), instrumental daily living activities (Lawton), nutritional status, mini mental scores, and geriatric syndromes like osteoporosis, incontinence, falls etc. were recorded. It was questioned whether if patients knew geriatrics, and if they knew and truly described geriatrics, they were asked how they had learned. Patients who knew the geriatrics were asked whether they applied to any of the centers with a geriatrician Ankara. Ankara University Ethical committee 25.06.2018 (No: 11-747-18).

\section{Statistics}

Statistical analysis was performed using SPSS version 22.0. Data was expressed as mean \pm standard deviation (SD). The strength of association between variables was tested by Pearson's correlation coefficient. The statistical significance between groups was determined with Student's t-test. Chisquare test was used for the proportional correlations. P values of less than 0.05 were considered as significant.

\section{Results}

A total of 314 patients were included in the study. The mean age of the participants was $68.96 \pm 5.77 .158(50.31 \%)$ of the participants were female and $156(49.68 \%)$ were male. Of the participants, $235(74.84 \%)$ were married and $79(25 \%)$ were widowed/unmarried (Table 1).

Of the participants, 158 (50.31\%) were living with their spouse, $76(24.20 \%)$ with their spouse and children, $45(14.33 \%)$ with their children, and 44 (14.01\%) were living alone (Table 1).

Of the participants, 244 (77.70\%) were living in their own house, $43(13.70 \%)$ were living in a rented house, $26(8.30 \%)$ were leaving in a relative's home and $1(0.30 \%)$ lived in a nursing home (Table 1).

Ninety-three $(29.60 \%)$ of the participants were not literate, $45(14.30 \%)$ were literate, $104(33.10 \%)$ were primary school graduates, $20(6.40 \%)$ were secondary school graduates, and $36(11.50 \%)$ were high school graduates and $16(5.10 \%)$ had university or higher education (Table 1).

The participants' number of medicines was $3.37 \pm 2.76$, Katz's daily living activities score was $5.86 \pm 0.514$, Lawton instrumental activity of daily living scores $7.75 \pm 7.8$, mini nutritional assessment scores $13.61 \pm 1.95$, mini mental evaluation scores $24,16 \pm 4.33$ and geriatric depression scores were found as $4.68 \pm 3.77$ (Table 1).

According to verbal statements and medications, 173 (55.1\%) of the participants had hypertension, 101 (32.20\%) had diabetes mellitus, 67 (21.50\%) had coronary artery disease, 58 (18.60\%) had hyperlipidemia, $52(16.60 \%)$ had asthma/ COPD, $43(13.70 \%)$ had benign prostatic hypertrophy, $29(9.20 \%)$ had hypothyroidism, $25(8.0 \%)$ had osteoporosis, $16(5.10 \%)$ had rheumatological disease, $13(4.10 \%)$ had atrial fibrillation, 12 (3.80\%) had depression, 11 (3.50 \%) had malignancy, 10 (3.20\%) had cerebrovascular disease, eight (2.60\%) had congestive heart failure, three $(1.00 \%)$ had peripheral arterial disease and two $(0.60 \%)$ had chronic kidney disease (Table 2$)$.

Only 14 of the participants said they knew geriatrics, but only nine $(2.88 \%)$ were able to correctly identify what geriatrics is. 
While four of these participants (1.70\%) had education level less than five years, five (6.90\%) of the participants were educated for six and more years $(p=0.032)$.

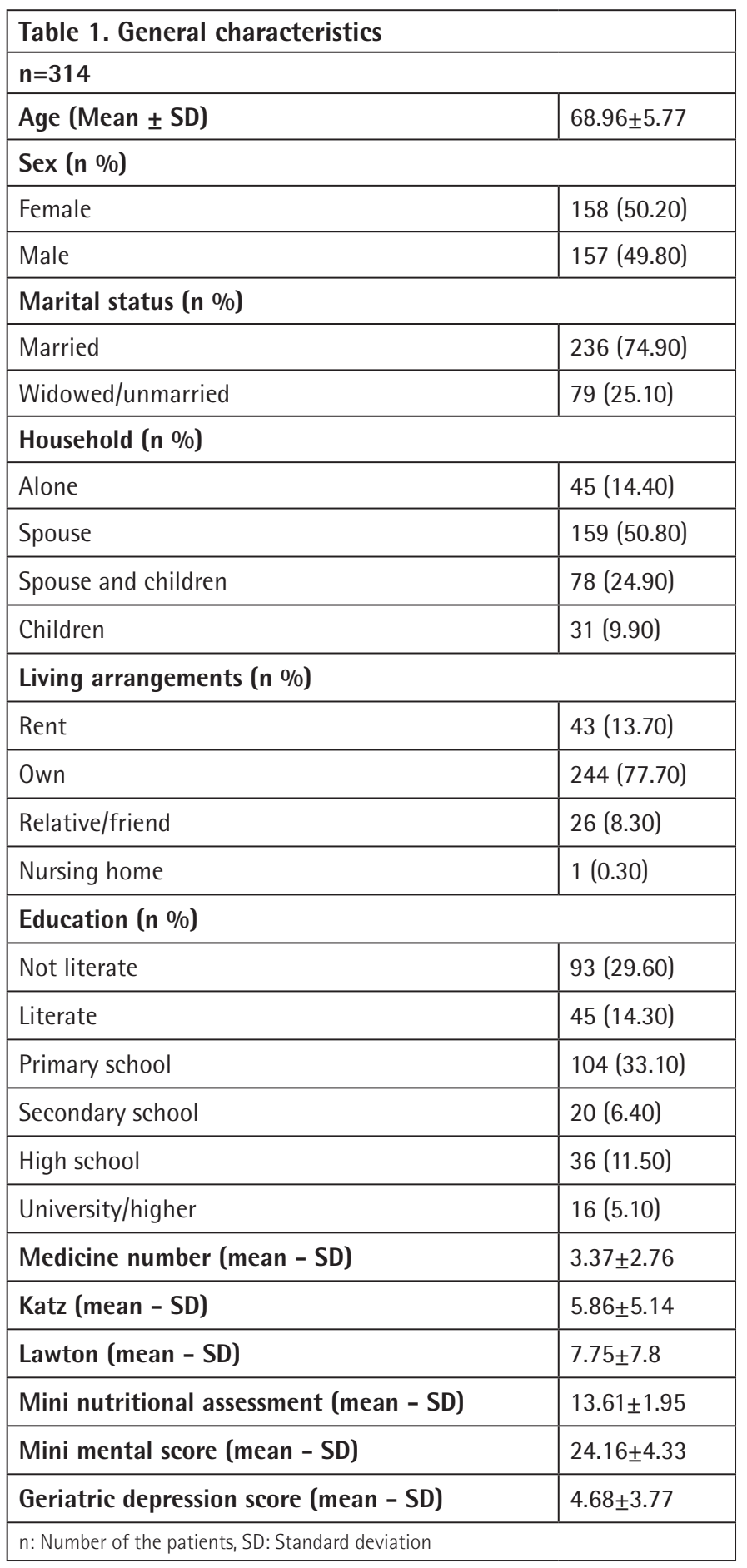

Older adults, those who know geriatrics are statistically significantly older, respectively 75 vs 68 years of age $(p=0.012)$; had fewer children, respectively two vs three $(p=0.016)$; higher mini mental scores, respectively 29 vs 25 $(p=0.002)$. (Table 3$)$

\section{Discussion}

Altindag (8) is a district with a population of $10.91 \%$ older adults. $50.7 \%$ of the population are females. $62.2 \%$ of the population is married. $58 \%$ are primary, middle and high school graduates, 15\% are university graduates and 15\% are in other education. These rates seem to coincide with our data.

To compare the characteristics and rates of geriatric awareness in the literature, we searched the terms "geriatrics" and "awareness" in Web of Sciences, Pubmed, EBSCO, Library of congress, California state Library, Acad Search Prem, Google and Yandex. We did not find any community-based or hospitalbased study in the literature. In the literature, which is made of publications close to the property we were looking for was from Turkey, which was published from Ankara Gazi University. Here around 200 patients in the waiting rooms of the hospital

\begin{tabular}{|l|l|}
\hline Table 2. Diseases & $\mathbf{n}(\%)$ \\
\hline Hypertension & $173(55.10)$ \\
\hline Diabetes mellitus & $101(32.20)$ \\
\hline Coronary artery disease & $67(21.50)$ \\
\hline Hyperlipidemia & $58(18.60)$ \\
\hline Asthma/Chronic obstructive pulmonary disease & $52(16.60)$ \\
\hline Benign prostatic hypertrophy & $43(13.70)$ \\
\hline Hypothyroidism & $29(9.20)$ \\
\hline Osteoporosis & $25(8.00)$ \\
\hline Rheumatological disease & $16(5.10)$ \\
\hline Atrial fibrillation & $13(4.10)$ \\
\hline Depression & $12(3.80)$ \\
\hline Malignancy & $11(3.50)$ \\
\hline Cerebrovascular disease & $10(3.20)$ \\
\hline Congestive heart failure & $8(2.60)$ \\
\hline Peripheral arterial disease & $3(1.00)$ \\
\hline Chronic renal disease & $2(0.60)$ \\
\hline Osteoporosis & $25(8.00)$ \\
\hline Malignancy & $11(3.50)$ \\
\hline n: Number of the patients & \\
\hline
\end{tabular}

Table 3. Statistically significant factors between subjects that are aware and unaware of geriatrics

\begin{tabular}{|l|l|l|l|}
\hline & Aware $\mathbf{n}(\%), 9(2 \%)$ & Unaware $\mathbf{n}(\%), \mathbf{3 0 5}(\mathbf{9 7} \%)$ & p value \\
\hline Age & $75(67-88)$ & $68(55-86)$ & $0.012^{*}$ \\
\hline Number of children & $2(1-5)$ & $3(0-8)$ & $0.016^{*}$ \\
\hline Mini mental score & $29(24-30)$ & $25(10-30)$ & $0.002^{*}$ \\
\hline
\end{tabular}


were included in the survey, and awareness rate hit 11.6\% (9). In comparison, this study population has a mean age of around 40 in a university, with a center of geriatrics, and the rate is quite low. We can argue that this is the first community-based study evaluating geriatrics awareness.

Since we could not compare the awareness rate, we wanted to have an idea about whether we go to a relatively homogenous group by evaluating the prevalence of diseases in the older adults. In our study, diabetes mellitus prevalence is $30 \%$, recently Gümüşsoy et al. (10) published a study from Turkey with similar diabetes prevalence rates in the older adults population, also TURDEP study had similar diabetes prevalence rates among Turkish older adults patients (11). Similarly, the prevalence of hypertension in our study was $55.1 \%$, which is consistent with the Turkish hypertension prevalence study (12). Finally, the total asthma/COPD prevalence was similar to the literature (13). Since we could not reach the data that we could refer to the geriatric awareness in the literature, we compared the chronic diseases of the patients, we thought that we obtained similar results in the literature, so that the population we screened could represent or at least form an opinion about geriatric awareness of the older adults living in the community.

When we compared those, who knew the geriatrics and those who did not know what the geriatrics is, we found that those who knew what geriatrics were statistically significantly older than those who did not know, 75 years of age vs 68 years of age respectively $(p=0.012)$. This may be due to the fact that more geriatric syndrome emerged with advanced age and there being 10 years vs three years for the possibility of intersection with a geriatrician.

We found that participants who knew what geriatrics has statistically fewer number of children when compared with the ones who did not knew, two children vs three children $(p=0.016)$ respectively. Although statistically significant we have some doubts. First, we have limited number of samples in this group. Secondly, having less number of children may be a sign of another situation like higher education level. Also, these group of participants are found to be the ones living with their spouse only in subgroup analysis. For this reason, although this group may be more likely to seek better quality medical care because of the limited availability of social support, we cannot support this view and suggest that more participants should be reached, since only two of the participants who knew what geriatrics is under a geriatrician follow up.

Lastly, we found that those who knew what geriatrics has significantly higher scores in mini mental test when compared with the ones who did not knew, 29 vs 25 ( $p=0.002$ ) respectively. We can comment that mini mental score may be a sign of any participants' general awareness. We can support this view: We detected that three participants who were detected that they did not know what geriatrics had geriatrician examination in the last three years and their median of mini mental score was 21. According to this result, any participant may still be unaware of what geriatrics is despite being under follow up as mini mental score lowers.

In general, participants with geriatrics awareness were found to be older in age, have higher mental scores and have less children. In subgroup analysis of all nine participants with geriatrics awareness, only education more than five years was statistically significant variable. The prevalence of geriatrics awareness was increased in those with higher education. We think that it would not be wrong to interpret that the "white collared" of the older adults are more aware of geriatrics.

If we revert to the main goal of the study, geriatrics awareness; the prevalence of geriatrics awareness was only $2.88 \%$ in this study. Two of these nine people who knew the geriatrics were a man and his wife working in Hacettepe University Anatomy department, which is close to geriatrics department. The remaining seven people were in two districts among eight different districts of Altındağ. Four of them in one district and three of them in another district. And all these four and three participants were the ones participating the survey respectively making us doubt if they were aware or they learned from each other. Lastly, six out of nine patients were detected to have an at least one admission to a medical center with a geriatrician. Five of these nine participants did not know how they learned about geriatrics, two were a married couple who retired from a university with a geriatrics department and they were under follow up there, one had lost his mother in a geriatrics clinic and one had heard from news.

Finally, as we stated in the introduction and aim, as the end of 2018 , total number of geriatricians is only $1 \%$ of optimal need of Turkey. In our study, we found only 3\% geriatrics awareness among target population in the community. This study can be accepted as the main reflection of this insufficiency on the community.

In the $20^{\text {th }}$ year, in the capital city of Turkey, with the highest number of geriatrician and geriatric centers per population, awareness of geriatrics is found to be too low. We are aware that, to generalize all these results to whole country and to be able to detect their consistency, we need more communitybased surveys. But here concluding that it is only the community that is not aware of geriatrics will not be fair. Considering that less than $5 \%$ of these participants do not have any chronic diseases, it will not be wrong to think that as much as the community, health personnel also is not aware of importance of or geriatrics itself, since $95 \%$ of these participants admit to a physician at least every three months for their prescribed medicines, and it seems that most of them have never heard 
about geriatrics. Again, looking at the number of geriatricians in the 20th year of geriatric practice in Turkey, state policies should work harder like geriatricians in order to make the geriatrics more known, functional and more preferable by physicians as a specialty.

\section{Study Limitations}

We reached to the older adults in eight districts so the data is hard to generalize and since awareness prevalence is so low it is hard to make comparative statistics between the older adults that is aware and unaware of geriatrics.

\section{Conclusion}

In our country, awareness of geriatrics is very low in its $50^{\text {th }}$ year. In order to increase the awareness of geriatrics, we think primarily geriatricians should find ways to increase awareness by the government, physicians and community.

\section{Ethics}

Ethics Committee Approval: Ankara University Ethical committee 25.06.2018 (No: 11-747-18).

Informed Consent: Informed consent was taken from every patient.

Peer-review: Externally peer-reviewed.

\section{Authorship Contributions}

Surgical and Medical Practices: V.A., R.B., Ç.C., H.S.Ö., Concept: V.A., R.B., D.M.S., T.T., H.S.Ö., C..C., A.Y., S.A., M.V., Design: V.A., R.B., D.M.S., T.T., Data Collection or Processing: V.A., R.B., H.S.Ö., Ç.C., Analysis or Interpretation: V.A., R.B., D.M.S., T.T., H.S.Ö., Ç.C., A.Y., S.A., M.V., Literature Search: V.A., R.B., Ç.C., Writing: V.A., R.B., Ç.C., D.M.S., T.T.

Conflict of Interest: No conflict of interest was declared by the authors.
Financial Disclosure: The authors declared that this study received no financial support.

\section{References}

1. Devi $D$, Srivastava $R$, Dwivedi BK. A critical review of concept of aging in Ayurveda. Ayu 2010;31:516-519.

2. Gerrit B, Jazzar I, Isyan R. (treatise on forgetfulness), London, 1995.

3. Pitskhelauri GZ, Dzhorbenadze DA. [Gerontology and geriatrics in the works of Abu Ali Ibn Sina (Avicenna) (on the 950th anniversary of the manuscript, Canon of Medical Science)]. Sov Zdravookhr 1970;29:68-71.

4. Lascaratos J, Poulacou-Rebelacou E. The roots of geriatric medicine: care of the aged in Byzantine times (324-1453 AD). Gerontology 2000;46:2-6.

5. Barton A, Mulley G. History of the development of geriatric medicine in the UK. Postgrad Med J 2003;79:229-234.

6. Vladimir I, Vladimir P. New bibliography of scientific papers by Dr. Laza K. Lazarević. Glas SANU - Medicinske Nauke, 2002:37-51.

7. Hatemi H. Geriatri'nin Türkiye'de "Illk" lerinden Prof. Dr. Şefik KAYAHAN. Turkish Journal of Geriatrics 1998;1:43.

8. https://www.endeksa.com/tr/analiz/ankara/altindag/demografi.

9. Kızılarslanoğlu MC, Kılıç MK, Özsürekci C, Köklü H, Ülger Z. Geriatri Bilim Dalı Olan Bir Üniversite Hastanesinde Geriatri Tanınma Oranları. İç Hastalıkları Dergisi 2013;20:135-140.

10. Gümüşsoy $M$, Bahşi $R$, Mut Sürmeli $D$, Turgut $T$, Selvi Öztorun $H$, Atmış $V$, Varlı M, Aras S. Insulin Misusage and Affect of Insulin Education in the Elderly. Van Med J 2018;25:323-331.

11. Satman I, Omer B, Tutuncu Y, Kalaca S, Gedik S, Dinccag N, Karsidag K, Genc S, Telci A, Canbaz B, Turker F, Yilmaz T, Cakir B, Tuomilehto J; TURDEPII Study Group. Twelve-year trends in the prevalence and risk factors of diabetes and prediabetes in Turkish adults. Eur J Epidemiol 2013;28:169180.

12. Sengul $S$, Akpolat T, Erdem $Y$, Derici U, Arici M, Sindel S, Karatan O, Turgan C, Hasanoglu E, Caglar S, Erturk S; Turkish Society of Hypertension and Renal Diseases. Changes in hypertension prevalence, awareness, treatment, and control rates in Turkey from 2003 to 2012. J Hypertens 2016;34:12081217.

13. Murtagh E, Heaney L, Gingles J, Shepherd R, Kee F, Patterson C, MacMahon $J$. Prevalence of obstructive lung disease in a general population sample: the NICECOPD study. Eur J Epidemiol 2005;20:443-453. 